\title{
Articles
}

\section{THE PERSPECTIVE OF PENSION SYSTEM REFORMS IN THE NEW MEMBER STATES}

\author{
Mejra Festić, Jože Mencinger*
}

\begin{abstract}
:
Because of growing awareness of financial needs for public pensions, attention has been focused on privatisation of the pension systems. While the privatisation of pension funds can encourage development of capital markets in New Member States, equity investment in transition economies is even more volatile than in the "old" capitalist countries. Privatised pension system coincides with investment risks, higher administrative costs, and inability of private markets to provide retirees with affordable, indexed and certain annuities. Namely, private sector may not provide enough investment projects to efficiently absorb mandated pension savings and the expected pension income is subject to a number of risks: poor and volatile investment returns, longevity, and inflation eroding the purchasing power of pensions. Indeed, the PAYG system appears to be the only viable system to perform well in terms of risk and volatility of returns.
\end{abstract}

Keywords: pay-as-you-go, ageing of population, pension funds, cyclicality, financial burden.

JEL Classification: J23, J31, J48, O15

\section{Introduction}

In the communist era, pensions were financed on pay-as-you-go (PAYG) basis through taxes and employers' social contributions. Benefits were generally a mix between a flat-rate component and a percentage of the worker's previous income. People working in specific sectors, especially industry, were favoured in terms of retirement ages and benefit levels. Economic and social consequences of transition posed additional strain on pension systems. Thus, a majority of Central and Eastern European countries have undertaken radical reforms of their pension systems. A three-pillar system (PAYG tier, compulsory pension funds, and voluntary pension funds - as a possible framework) was introduced in many New Member States (NMS).

* Mejra Festić, Faculty of Economics, University of Maribor and EIPF, Ljubljana, Slovenia (mejra.festic@uni-mb.si); Jože Mencinger, Faculty of Law, University of Ljubljana and EIPF, Ljubljana, Slovenia (Joze.mencinger@eipf.si). 
The debate on pensions in NMS reveals the role of the international actors in dictating the policies to be implemented by national governments. In 1994, the World Bank published a document "Averting the Old-Age Crisis" (WB 1994): Policies to protect the old and to promote growth that came out suggesting serious downsizing of the first pillar. It was clearly in favour of establishing mandatory funded second pillar for pensions, following the main trends of privatisation of the public services advocated by the Washington consensus. The document was the starting point for the debates on pensions advocating the privatisation of old-age insurance. The shift from pay-as-you-go (PAYG) financing to private funding of pensions was expected to provide needed capital for investment and to help developing national financial markets.

The goal of our contribution is to present pension systems and problems related to them. In the first chapter, an overview of trends and macroeconomic background in the NMSs is presented. An empirical analysis of the determinants of pensions" share in GDP in the EU in the second chapter serves to introduce major determinants of their financial burden. In the third chapter, we summarize the reforms and experiences of the NMS. The perspectives of pension system reforms and the implications for economic policy are portrayed in the last two chapters.

\section{Economic Background in the NMS and "Old" EU Countries}

The share of pensions in GDP in a country depends on its pension system, which is influenced indirectly by the age of population, retirement age, replacement rate ${ }^{1}$ and the level of economic development. The retirement age and the replacement rate are reflecting the existing pension system, the old age dependency ratio reveals the need for pensions expenditures, while the development level shows the capability of a country to provide their financing. Thus, an upward shift of the retirement age would decrease the share of pensions in GDP, while the replacement rate, ageing of population, and level of economic development should increase the share. There is a considerable diversity in the shares of pensions among EU Member States.

Expenditures for pensions or transfers from active population to pensioners are supposed to be the root of the financial problem. The debate on the threatening collapse of the public finance most often begins with data on the ageing of the population expressed by the growth of the old age dependency ratio defined as the ratio between number of persons older than 65 and number of persons between 15 and 64. The latter are supposed to bear economic burden caused by the former. ${ }^{2}$ However, actual data indicate that despite considerable increase in the old age dependency ratio between

1 Replacement rate is defined as the ratio of income from pensions of persons aged between 65 and 74 years and income from work of persons aged between 50 and 59 years.

2 According to Eurostat data the nominator of the ratio, i.e. the share of people over 65 would in the EU27 increase from 17.08 percent in 2008 to 28.81 percent in 2050. Using the Eurostat demographic projections the situation among NMS would be most critical in Slovenia with the old age dependency ratio of 59 percent, followed by Poland, Bulgaria, Slovakia, the Czech Republic and Romania with the ratios close to 55 percent. In Old Member States (OMS), the situation would be the worst in Italy followed by Spain, Greece, and Germany. Extremes on the opposite side are Luxemburg, the UK and Cyprus with the old age dependency ratio of 38 percent followed by Sweden and Denmark. 
1995 and 2005 the share of pensions in GDP stabilized or even decreased slightly. Indeed, the growth of the average pension lagged behind GDP growth. Mencinger (2007) therefore argued that the public pension expenditures (the transfer of incomes from active to retired population) are not eroding public finance.

Graph 1

Average Shares of Pensions in GDP

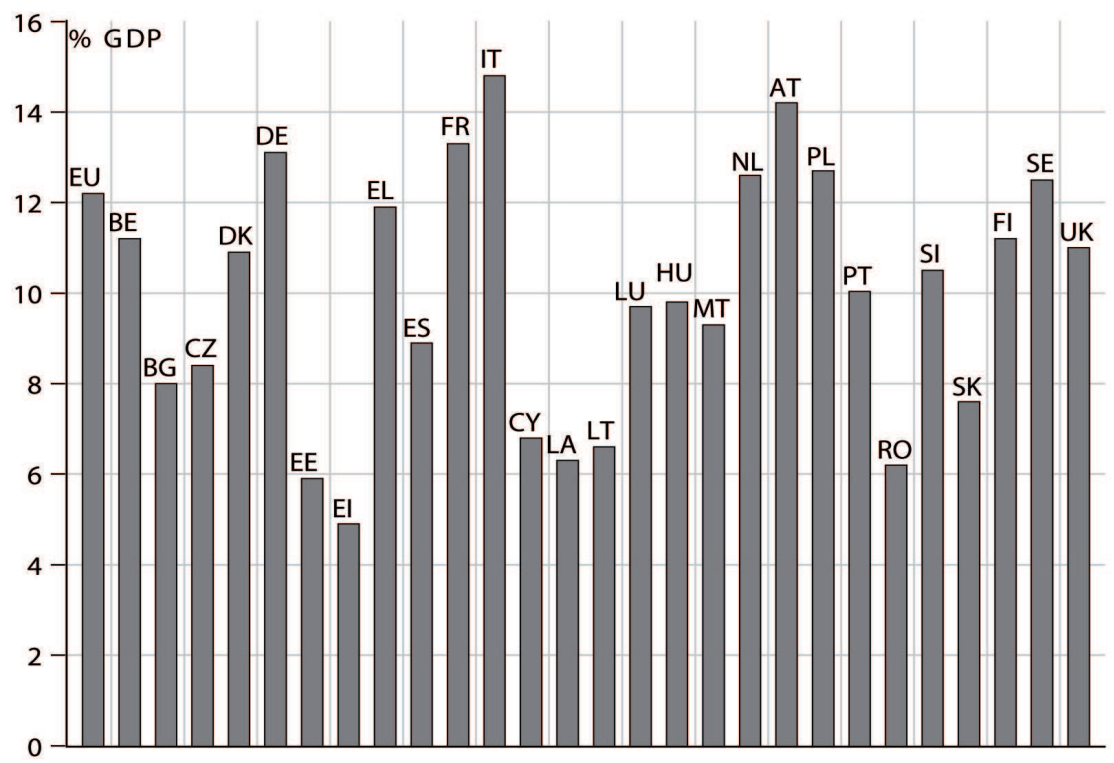

Source: Eurostat (2008).

For the most recent period for which data are available, the determinants of the burden of pensions to the public finance can be summarized by a regression equation in which the share of pensions in GDP is the dependent variable while the retirement age, the replacement rate, the old age dependency ratio, and the level of GDP per capita are independent variables. ${ }^{3}$

\section{Pensions/GDP $=\mathbf{b}_{0}+\mathbf{b}_{1}{ }^{*}$ Old age ratio $+\mathbf{b}_{2}{ }^{*}$ Retirement age + $b_{3}{ }^{*}$ GDP/capita $+b_{4}{ }^{*}$ Replacement rate}

3 One could find additional determinants of the share of pensions in GDP, for example, employment rate or a shift from a socialist to a market economy, or a different form of the equation specification. 
According to the equation, ${ }^{4}$ an increase of the old age ratio by one percentage point increases the share of pensions in GDP by 0.325 percentage points and of the replacement rate by 0.095 percentage points while an increase of retirement age by one percentage point decreases the share by 0.656 percentage points. Furthermore, the share of pensions in GDP grows with the level of development.

The level of development and the age of population can be in this context considered exogenous, while the retirement age and the replacement rate can be treated as economic policy variables. The differences in the retirement age among the countries indirectly indicate in which countries the share of pensions in GDP could be lowered by increasing the retirement age to a benchmark age (the existing EU-27 average). Malta, France, Italy, Lithuania, Luxemburg, Hungary, Poland, Slovenia and Slovakia belong to this group. Bulgaria, Ireland, Romania, and Sweden have the retirement age much higher than the EU-27 average; hence, they have already used some of the potential impact of increasing retirement age. An alternative to increasing retirement age is lowering replacement rate; the potential to use it exists in Austria, Luxemburg, Sweden, Bulgaria, Portugal, Poland, Italy and France in which replacement rate considerably exceeds the benchmark i.e. the EU27 average.

The equation indirectly indicates that the threats of "greedy pensioners" for the fiscal balances in NMS are highly exaggerated. Substantial differences among EU countries regarding the shares of pensions and their economic policy determinants (retirement age and replacement rate) namely reveal that possibilities for adaptation exist. Secondly, while ageing cannot be avoided the effects of ageing can be successfully countered by reasonable increases of the retirement age provided there are jobs available. ${ }^{5}$ The

4 The addition of dummy variables for NMS or employment rates did not improve regression results. Thus, the original specification was retained. OLS estimation of the regression equation gives the following results.

\begin{tabular}{|c|c|c|c|c|}
\hline \multicolumn{3}{|c|}{ Dependent Variable: Share of pensions in GDP } & & \\
\hline \multicolumn{5}{|l|}{ Method: Least Squares } \\
\hline \multicolumn{5}{|c|}{ Included observations: 25} \\
\hline & Coefficient & Std. Error & t-Statistic & Prob. \\
\hline $\mathbf{b}_{0}$ & 33.14 & 13.49 & 2.456 & 0.0233 \\
\hline$b_{1}$ (old age ratio) & 0.325 & 0.104 & 3.112 & 0.0055 \\
\hline$b_{2}$ (retirement age) & -0.656 & 0.217 & -3.024 & 0.0067 \\
\hline$b_{3}$ (development level) & 0.052 & 0.013 & 3.995 & 0.0007 \\
\hline$b_{4}$ (replacement ratio) & 0.095 & 0.045 & 2.096 & 0.0490 \\
\hline R-squared & 0.685 & \multicolumn{2}{|c|}{ Mean dependent var. } & 10.09 \\
\hline Adjusted R-squared & 0.622 & \multicolumn{2}{|c|}{ S.D. dependent var. } & 2.755 \\
\hline S.E. of regression & 1.693 & \multicolumn{2}{|c|}{ Akaike info criterion } & 4.067 \\
\hline Sum squared resid. & 57.32 & \multicolumn{2}{|c|}{ Schwarz criterion } & 4.311 \\
\hline Log likelihood & -45.84 & \multicolumn{2}{|c|}{ Hannan-Quinn criter. } & 4.135 \\
\hline F-statistic & 10.88 & \multicolumn{2}{|c|}{ Prob (F-statistic) } & 0.000 \\
\hline
\end{tabular}

Source of data: Eurostat (2007).

5 Economic growth should be according to modern growth theories limitless because it is based on knowledge and growing share of services in GDP. It seems, however, that mankind is forced to invent new and new services to create jobs and incomes for those who are pushed out of traditional economic activities by labour saving technological change. The root of the problem is therefore not in the ageing of the population but in the limitlessness of economic growth and its job creation ability. 
postponement of retiring therefore appears to be the most efficient manner to counter financial strain of pensions. It has twofold effects; it increases the payments to the pension funds and, even more so, reduces, the expenditures (the number of pensioners and the number of years, a pensioner collects the pension). For example, by increasing the retirement age from 60 to 65 , the contributions to the pension funds would increase inflows and reduce outflows by at least 10 percent each; the average life expectancy in the EU at 60 is namely 21.2 years, at 65 it is 17.2 years. To postpone retiring can therefore be easily made financially attractive. Thirdly, the sole fact that since 1990, the shares of pensions in GDP in "old" EU states fluctuated around country specific averages (they have increased significantly in Austria, Italy, Portugal, and decreased in Belgium, Luxemburg, the Netherlands) indicates that there has been no real worsening of the financial state which implies that there is no need for radical changes of the existing systems. This is indirectly confirmed by the OECD calculations of the amount of public spending on old age pensions in 2000 and 2050 provided the systems do not change. The calculation which should serve as a confirmation that changes are needed, are astonishing because of modest rather than large changes in public spending over a period of half a century (Mencinger, 2008).

The share of pensions in GDP in NMS (except Slovenia and Poland) and particularly in three Baltic states is considerably lower than in the EU15. Pensioners in NMS countries were apparently among the victims of transition. Let us add that demographic movements and structures in NMS have been similar to movements and structures in the "old" Europe (Disney, 2003). It is expected that working age population will decline because of low fertility rates (in the Czech Republic even lower than in the least fertile EU-15 - Italy, Greece, Spain), while life expectancy is supposed to increase significantly, which would alleviate negative impact of low fertility rates on the size of population. This creates higher old age dependency ratio and presents a considerable concern for economic and social outlook of the countries.

Transition brought a sharp decline in output and employment, which severely strained pensions systems in NMS (Augustinovics, 2003), particularly because governments opened up disability and early retirement provisions to alleviate social cost of largescale unemployment. This was more costly than direct provision of unemployment benefits and placed a strain on pension scheme financing, causing a sharp increase in the pension system dependency ratio in just a few years (Dupont, 2004, p. 58). The economic recovery which followed was mainly a result of productivity improvement and did not induce large-scale job creation. A growing number of pensioners in the first years of transition, due to early retirement caused by enterprises ' restructuring and economic recession, resulted in increased pension expenditures. But, the NMS have been growing relatively fast and their GDP per capita has converged to the EU average which would allow higher shares of pensions in GDP. Economic growth namely lessens the share of pensions in GDP directly by increasing the denominator, and indirectly by easing the redistribution of incomes from active population to pensioners. 
Table 1

Pensions in the New Member States

\begin{tabular}{|l|c|c|c|}
\hline & $\begin{array}{c}\text { pension } \\
\text { expenditures/ } \\
\text { GDP(2000/2006) }\end{array}$ & $\begin{array}{c}\text { population over 65 } \\
\text { (in \%of otal } \\
\text { population) }\end{array}$ & $\begin{array}{c}\text { old-age dependency ratio }= \\
\text { population(+65)/ } \\
\text { population(15-64) }\end{array}$ \\
\hline Czech Republic & $8.5 / 8.4$ & $14.2 / 14.4$ & $20.0 / 20.2$ \\
\hline Hungary & $8.4 / 10.0$ & $15.8 / 15.9$ & $22.9 / 23.2$ \\
\hline Poland & $12.6 / 12.4$ & $13.3 / 13.4$ & $18.9 / 19.0$ \\
\hline Slovakia & $7.5 / 7.3$ & $11.7 / 11.9$ & $16.4 / 16.5$ \\
\hline Slovenia & $11.1 / 10.3$ & $15.6 / 15.9$ & $22.2 / 22.7$ \\
\hline Estonia & $6.7 / 5.9$ & $16.7 / 17.1$ & $24.5 / 25.1$ \\
\hline Latvia & $9.5 / 6.1$ & $16.8 / 17.1$ & $24.4 / 24.8$ \\
\hline Lithuania & $7.8 / 6.4$ & $15.3 / 15.6$ & $22.5 / 22.7$ \\
\hline Bulgaria & 17.6 & $17.2 / 17.3$ & $24.9 / 24.9$ \\
\hline Romania & $6.7 / 6.5$ & $14.8 / 14.9$ & $21.2 / 21.3$ \\
\hline EU-27 & 11.9 & $16.8 / 16.9$ & $24.9 / 25.2$ \\
\hline
\end{tabular}

Source: Eurostat (2008).

In almost all NMS, the old-age dependency ratio (Table 1) weights on the increase in pension spending. On the average, if there were no offsetting factors, demographic pressure would push public pension spending significantly upwards. However, almost all of the demographic pressure is projected to be offset by increasing employment rates, lower take-up of pensions, and lower benefit ratios (Salomäki, 2006, pp. 20-25). The magnitude of the effects of increasing employment rates varies substantially across countries, depending on the estimated effects of the recently undertaken labour market and pension system reforms. Countries with current low rates of employment (Lithuania, Poland and Slovakia) are projected to have the largest offsetting effect from increasing employment. According to projections, higher employment rate, lower structural unemployment rate, higher employment rate of older workers, and higher labour productivity growth might be expected to have only a marginal effect on public pension expenditures relative to GDP (Salomäki, 2006, pp. 39-46).

\section{An Overview of Pension Systems and Reforms in the New Member States}

Economic and demographic factors have had substantial impact on the choice of reform model in the New Member States (Müller, 2002). Public and private (mandatory/ voluntary) pension schemes (depending on the role of the state as a regulator, manager and provider), the benefit structure and the dominant financing method (defined in terms of earning-related/PAYG or contributions-related/funded system) show the fragmentation of pension systems reforms in different pillars (Mitchell and Dykes, 2000). The crucial issue concerning the pension scheme is the relation between contributions and benefits on one side; and, on the other side, the nature and extent of the consequent redistribution. 
Reforms implying full or partial pension privatisation started in Hungary (1998), Poland (1999), Latvia (2001), Bulgaria and Estonia (2002). Lithuania, Romania and Slovakia considered this type of reform but postponed it, whereas Slovenia and the Czech Republic dismissed privatisation of the old age protection.. Many NMS still rely on their public PAYG scheme as the only provider of mandatory old-age insurance. Some of them introduced substantial parametric reforms, yet relatively little effort has been made to explain their policy choice between recommendations of the new pension orthodoxy and a more moderate approach to the pension reform (Nelson, 2001). The NMS can be clustered in three groups according to the pension system architecture chosen:

a) Latvia and Poland, where pensions are financed on PAYG basis but entitlements are determined as in private defined-contribution pension funds and the pension is an annuity drawn from the accumulated capital sum.

b) Hungary, Bulgaria, Estonia, Lithuania and Slovakia, where new pension systems have three pillars and the public system remained a well defined benefit scheme.

c) Czech Republic, Slovenia and Romania, where the only mandatory system is the PAYG.

The Czech Republic and Slovenia dismissed the idea of pension privatisation and combined a public mandatory PAYG scheme with a supplementary funded tier. In the Czech Republic, the second tier consists of a voluntary private scheme offering personal pension plans, whereas in Slovenia there are three supplementary pension schemes: a mandatory scheme for formerly privileged branches, a voluntary private scheme for occupational and personal plans, and a pension fund for privatisation certificates. The Czech and Slovenian reform measures remained within boundaries of the Bismarckian-Beveridgean pension paradigm, while a partial privatisation of old insurance has been enacted in Poland and Hungary (Augustinovisc, 2003, p. 102).

In Slovenia, the government decided in 1996 to decrease employers contributions from $15.5 \%$ to $8.85 \%$ of gross wage to enhance competitiveness of labour intensive industries (Stanovnik, 2006). The reform in 1999 increased the age criterion for the earliest entrance into the pension system. The period for calculating the pension base has been extended to the best eighteen years and a maximum pension was restricted to 4-times minimum pension base. Employers are obliged to pay normal contribution to the first pillar and additional contribution to the mandatory supplementary pension scheme; additional contributions are to provide the insured person with an occupational pension (Novak, 2004). 
Table 4

\section{Pension Systems}

\begin{tabular}{|c|c|c|c|c|c|}
\hline & Czech Republic & Hungary & Poland & Slovakia & Slovenia \\
\hline $\begin{array}{l}\text { Compulsory } \\
\text { membership }\end{array}$ & $\begin{array}{l}\text { For employees, } \\
\text { self-employed, } \\
\text { persons with the } \\
\text { same status as } \\
\text { employees. }\end{array}$ & $\begin{array}{l}\text { For employees, } \\
\text { cooperative } \\
\text { members, } \\
\text { self-employed } \\
\text { persons, } \\
\text { unemployed } \\
\text { persons. }\end{array}$ & $\begin{array}{l}\text { For employees, self- } \\
\text { employed, artists, } \\
\text { service-providers } \\
\text { and civil servants, } \\
\text { sportsmen. }\end{array}$ & $\begin{array}{l}\text { For employees, } \\
\text { cooperative } \\
\text { members, self- } \\
\text { employed persons, } \\
\text { unemployed } \\
\text { persons. }\end{array}$ & $\begin{array}{l}\text { For employees, self- } \\
\text { employed, farmers, civil } \\
\text { servants, unemployed. }\end{array}$ \\
\hline $\begin{array}{l}\text { Minimum } \\
\text { contribution } \\
\text { periods }\end{array}$ & $\begin{array}{l}25 \text { years, from } \\
\text { the age of } 65: 15 \\
\text { years. }\end{array}$ & $\begin{array}{l}40 \text { years (taking } \\
\text { time for bringing } \\
\text { up children and } \\
\text { studying into } \\
\text { account), from } \\
\text { the age of } 62: 20 \\
\text { years. }\end{array}$ & $\begin{array}{l}\text { Year of birth before } \\
\text { 1949:20 years for } \\
\text { women and } 25 \text { years } \\
\text { for men. }\end{array}$ & $\begin{array}{l}25 \text { years for full } \\
\text { pension; in the case } \\
\text { of early retirement: } \\
10 \text { years for women; } \\
20 \text { years for men. }\end{array}$ & 15 years \\
\hline $\begin{array}{l}\text { Standard } \\
\text { retirement } \\
\text { age }\end{array}$ & $\begin{array}{l}\text { Between } 53 \\
\text { and } 57 \text { years } \\
\text { for women } \\
\text { according to } \\
\text { the number of } \\
\text { children, } 60 \\
\text { years for men; } \\
\text { the standard } \\
\text { retirement age } \\
\text { will rise till } \\
2012 \text {. }\end{array}$ & $\begin{array}{l}62 \text { for men and } \\
\text { women }\end{array}$ & $\begin{array}{l}60 \text { years for women } \\
\text { and } 65 \text { years for men }\end{array}$ & $\begin{array}{l}60 \text { years for women } \\
\text { and man, women } \\
\text { depending on the } \\
\text { number of children, } \\
53 \text { to } 57 \text {; from } \\
2005 \text { the standard } \\
\text { retirement age has } \\
\text { risen to } 63 \text { years. }\end{array}$ & $\begin{array}{l}58 \text { to } 65 \text { years for men } \\
\text { and } 58 \text { to } 63 \text { for women; } \\
\text { graduated by the number } \\
\text { of years of insurance. }\end{array}$ \\
\hline $\begin{array}{l}\text { Amount of } \\
\text { pension }\end{array}$ & $\begin{array}{l}\text { Depending on } \\
\text { income and } \\
\text { periods of } \\
\text { insurance. }\end{array}$ & $\begin{array}{l}\text { Depending on } \\
\text { income and } \\
\text { periods of } \\
\text { insurance. }\end{array}$ & $\begin{array}{l}\text { Depending of the } \\
\text { reference wage } \\
\text { or salary and the } \\
\text { number of years of } \\
\text { insurance. }\end{array}$ & $\begin{array}{l}\text { Depending on } \\
\text { the duration of } \\
\text { employment, } \\
\text { occupational hazard, } \\
\text { sex, amount of } \\
\text { income during } \\
\text { active service. }\end{array}$ & $\begin{array}{l}\text { Depending on previous } \\
\text { income, years of } \\
\text { insurance, sex. }\end{array}$ \\
\hline $1^{\text {st }}$ pillar & $\begin{array}{l}\text { Compulsory } \\
\text { membership } \\
\text { financed by } \\
\text { contributions } \\
\text { based on } \\
\text { solidarity. }\end{array}$ & $\begin{array}{l}\text { State pension } \\
\text { (pensions are } \\
\text { financed by the } \\
\text { contributions } \\
\text { of the working } \\
\text { population). }\end{array}$ & $\begin{array}{l}\text { Each person or } \\
\text { employee maintains } \\
\text { a separate account } \\
\text { with social insurance } \\
\text { institution and } \\
\text { membership is } \\
\text { compulsory. }\end{array}$ & $\begin{array}{l}\text { Compulsory } \\
\text { financed by } \\
\text { contributions based } \\
\text { on the idea of } \\
\text { solidarity. }\end{array}$ & $\begin{array}{l}\text { State pension, pensions } \\
\text { are financed by } \\
\text { contributions of the } \\
\text { working population. }\end{array}$ \\
\hline $2^{\text {nd }}$ pillar & $\begin{array}{l}\text { Voluntary } \\
\text { private pension } \\
\text { insurance. }\end{array}$ & $\begin{array}{l}\text { Private pension } \\
\text { (setting-up of } \\
\text { a compulsory } \\
\text { pension fund). }\end{array}$ & $\begin{array}{l}\text { Obligatory for all } \\
\text { born after December } \\
\text { 1968. Part of the } \\
\text { pension contribution } \\
\text { by the insured person } \\
\text { is transferred to } \\
\text { the private pension } \\
\text { fund selected by the } \\
\text { entitled persons from } \\
\text { the list with the social } \\
\text { insurance institution. }\end{array}$ & $\begin{array}{l}\text { Fragmented } \\
\text { solidarity, } \\
\text { contributions are } \\
\text { paid to social } \\
\text { security and } \\
\text { transferred to } \\
\text { relevant fund. }\end{array}$ & $\begin{array}{l}\text { The pillar is split into } \\
\text { compulsory and voluntary } \\
\text { pension insurance. } \\
\text { The supplementary } \\
\text { compulsory insurance } \\
\text { is required only for } \\
\text { employees working under } \\
\text { strenuous conditions } \\
\text { harmful to their life. } \\
\text { This form of insurance is } \\
\text { favoured for tax purposes. }\end{array}$ \\
\hline $3^{\text {rd }}$ pillar & & $\begin{array}{l}\text { Voluntary private } \\
\text { pension (or live) } \\
\text { insurance. }\end{array}$ & $\begin{array}{l}\text { Voluntary, life } \\
\text { insurance premiums } \\
\text { are paid by employee } \\
\text { or employer to an } \\
\text { investment or to } \\
\text { a pension fund for } \\
\text { specific insurance. }\end{array}$ & $\begin{array}{l}\text { Voluntary private } \\
\text { pension insurance. }\end{array}$ & $\begin{array}{l}\text { Voluntary private } \\
\text { pension (or life) } \\
\text { insurance. }\end{array}$ \\
\hline
\end{tabular}

Source: GVG (2002), BACA (2007), DREE (2003), EC (2003), Natali (2004), Clon-Dominczak (2002), Disney (2001). 
In the Czech Republic, the first pillar consists of two sub-clusters. Each pension is based on the flat-rate basic amount equal for all pensioners, and the earnings-related portion financed through social contributions and related to employment (Grimmeisen, 2003). Reform in 1995 introduced a gradual increase in the retirement ages and generous conditions for early retirement for specific groups of employees. The resources of the social security were part of the state budget and surpluses were used for other purposes within the state budget or covering a negative balance in pension insurance (Mácha, 2006). A second tier voluntary old-age insurance was introduced in 1994 enabling employees to join open pension fund administered by private-profit making funds. A pension fund provides different types of pensions: old-age pension (conditional on the attainment of the age stipulated in the pension plan), disability pension (conditional on retirement due to disability), early retirement pension (upon expiry of a time period specific in the pension plan) and inheritance pension (conditional on the death of the beneficiary) ${ }^{6}$

In Slovakia, the new system was activated in January 2004; it is based on three main pillars. A first tier is financed in line with the traditional PAYG method. Pension benefits consist of benefits financed by contributions paid by employers, employees, and self-employed. The second tier is mandatory, fundamentally private, and fully funded. Financial resources come from the split of total contributions originally paid to the first pillar. The second and third pillar are voluntary, fully funded, and private. While the mandatory pillar is expected to provide between 50 and $60 \%$ of gross replacement rates, the voluntary one is expected to provide between 20 and $25 \%$ of replacement rates (Natali, 2004).

In Poland, the pension system is characterized by the coexistence of the old pension system and the new one adopted in 1999 (Clon-Dominczak, 2002). The first (public and mandatory) pillar consists of benefits related to revenues consistent with the PAYG mechanism but the amount of pensions is being related to the average life expectancy, contribution paid by employees and employers, economic and demographic factors. Early retirement possibilities were abolished. The second tier is mixed public-private and mandatory. Employees have the right to choose the private fund where to invest their contributions under the supervision of the state. At the time of retirement, savings in pension funds are used by insured persons to purchase an annuity provided by special private companies. The third pillar is not well developed due to a relative high level of the replacement rate granted by the first mandatory pillar (Orszag and Stiglitz, 2001).

In Hungary, government undertook a fundamental pension reform in 1997. The reform established partial and step-by-step funding and privatization of PAYG public pension system, which shifted the system into multi-pillar pension system. In Hungary and Poland, the reforms sustained the mandatory public pension scheme (PAYG) as the dominant pillar in the new mixed system, they postponed or left unresolved many of its systemic problems. By the end of the decade, these reforms were seen as insufficient and it was believed that further changes are required. Both governments at the end accepted privatisation proposals. This led to a lack of transparency in the implementations of the

6 The average portfolio in the Czech pension funds consists of bond (50\%), real estate (1.5\%), treasury bills (26\%), shares and unit certificates $(10 \%)$, cash $(9 \%)$, oher assets $(3 \%)$ and other investment (less than 0.5\%) (Mácha, 2006). 
reforms. The introduction of a multi-tier system with a significant private pre-funded component was the pillar of the reforms. Subsequent legislation worsened rather than improved the situation, and some of the counterproductive features of the system were left unaddressed. The public pillar remained as an impenetrable web of justified, redistributive social assistance and contribution-based, income-replacing social insurance, just as it was before the reform.

The pension systems in the Baltic states differ substantially. In Latvia, the system is based on three pillars. Estonia is typically multi-tiered; private companies play a much more important role than in Latvia where the first pillar consists of earningrelated pensions; the pension is directly linked to contribution paid by employers and employees which are virtually saved. Coverage is not universal but related to employment though it contains a guarantee of a subsistence pension to everybody. People with insufficient or no contributions are covered by social assistance schemes. The second tier (public and mandatory) - as supplementary public funded pensions - was introduced in 2001. The State Treasury regulates and manages the second pillar, whereas investment decisions are taken by an asset manager. Institutions involved in the management of funded schemes are under the supervision of a public body. Due to the fact that state is the actor with administrative, regulatory and provider role, the Latvian pension system is close to the Scandinavian type. The third tier is supplementary, voluntary and private, it can be occupational and individual; and it is run by private institutions (Orenstein, 2003). Lithuania is closer to the Bismarckian model and the supplementary schemes are voluntary instead of mandatory.

Table 4

Revised Pension System in Europe

\begin{tabular}{|l|l|l|l|}
\hline Individual savings & Voluntary funded & Voluntary funded & Voluntary funded \\
\hline $\begin{array}{l}\text { Occupational } \\
\text { schemes }\end{array}$ & Voluntary funded & Mandatory funded & Voluntary funded \\
\hline $\begin{array}{l}\text { Universal } \\
\text { mandatory system }\end{array}$ & Public PAYG & Public PAYG & $\begin{array}{l}\text { Public/Private funded } \\
\text { Public PAYG }\end{array}$ \\
\hline Revised families & $\begin{array}{l}\text { Bismarckian public PAYG } \\
\text { system }\end{array}$ & $\begin{array}{l}\text { Multi-pillar } \\
\text { private funded, public } \\
\text { PAYG }\end{array}$ & $\begin{array}{l}\text { Nordic } \\
\text { PAYG/funded public } \\
\text { systems }\end{array}$ \\
\hline Countries & $\begin{array}{l}\text { Continental, Southern } \\
\text { (Cyprus, Malta), and part of } \\
\text { Central Eastern Europe } \\
\text { (e.g. the Czech Republic) }\end{array}$ & $\begin{array}{l}\text { Anglo-Saxon } \\
\text { countries, Path } \\
\text { breakers (Denmark, } \\
\text { Netherlands })\end{array}$ & $\begin{array}{l}\text { Scandinavia and the } \\
\text { Baltic countries, and } \\
\text { part of Central and } \\
\text { Eastern Europe } \\
\text { (e.g. Poland, Hungary, } \\
\text { Slovakia) }\end{array}$ \\
\hline
\end{tabular}

Source: Natali (2004, p.19). 


\section{The Perspective of Pension System Reforms in the NMSs}

The slogan that private sector is more efficient than public sector does not help much when social services are considered; one should consider also social aspects of their privatiszation. It is more and more apparent than the neo-liberal model fails to deliver long-term economic and social benefits for vast majority of people. Indeed, privatisation can in many economic sectors contribute to full employment and poverty reduction. Meanwhile, social dimension of privatisation and liberalisation continued overwhelmingly worsening economic and social welfare, particularly in the period of sluggish productivity growth. The stampede towards privatisation and capital funding could not bring the solution; it could bring exacerbation of the real problems of social welfare in a democratic society in which rising inequality should lead to growing financial demands for public pensions.

Welfare of pensioners in the NMS depends on the level of development, transition model, and adopted pension reforms. This is indicated by the data in Table 5 . The shares of pensions in GDP between 2000 and 2006 lowered in all NMS except Hungary; they decreased most in all three Baltic states, where the shares of pensions in GDP are extremely low, incomes of the "old" less than 70 percent of incomes of the "young", and at risk of poverty rate of pensioners very high. Indeed, these three countries have most closely followed transition model based on Washington consensus, which is indicated by their high economic freedom indexes ${ }^{7}$.

Table 5

Welfare of Pensioners in NMS

\begin{tabular}{|c|c|c|c|c|c|c|c|c|c|}
\hline \multirow[t]{2}{*}{ Country } & \multirow{2}{*}{$\begin{array}{l}\text { Heritage } \\
\text { foundation } \\
\text { index of } \\
\text { economic } \\
\text { freedom } \\
\end{array}$} & \multirow[t]{2}{*}{$\begin{array}{l}\text { GDP level } \\
\text { EU27=100 }\end{array}$} & \multicolumn{2}{|c|}{$\begin{array}{l}\text { Share of pensions } \\
\text { in GDP (in \%) }\end{array}$} & \multicolumn{2}{|c|}{ Replacement ratio } & \multicolumn{2}{|c|}{$\begin{array}{l}\text { Incomes } \\
\text { of "old" } \\
\text { compared } \\
\text { to "young" }\end{array}$} & \multirow{2}{*}{$\begin{array}{c}\begin{array}{c}\text { At risk } \\
\text { of poverty } \\
\text { rate of } \\
\text { pensioners }\end{array} \\
2006\end{array}$} \\
\hline & & & 2000 & 2006 & 2005 & 2007 & 2005 & 2007 & \\
\hline EU15 & & 100 & 12.3 & 12.1 & 0.57 & 0.49 & & 0.84 & 16 \\
\hline Bulgaria & $64.6(7)$ & 38.1 & & 7.6 & 0.63 & 0.59 & 0.84 & 0.82 & 17 \\
\hline Czech Republic & $69.4(3)$ & 81.3 & 8.5 & 8.4 & 0.51 & 0.51 & 0.83 & 0.81 & 7 \\
\hline Estonia & $76.4(1)$ & 70.6 & 6.7 & 6.0 & 0.45 & 0.47 & 0.73 & 0.65 & 29 \\
\hline Latvia & $66.6(6)$ & 58.0 & 9.5 & 6.1 & 0.61 & 0.38 & 0.74 & 0.69 & 35 \\
\hline Lithuania & $70.0(2)$ & 61.0 & 7.8 & 6.4 & 0.47 & 0.40 & 0.81 & 0.69 & 23 \\
\hline Hungary & $66.8(5)$ & 63.5 & 8.4 & 10.0 & 0.61 & 0.58 & 1.01 & 0.97 & 12 \\
\hline Poland & $60.3(10)$ & 53.8 & 12.6 & 12.4 & 0.58 & 0.58 & 1.09 & 1.04 & 7 \\
\hline Romania & $63.2(8)$ & 40.6 & 6.7 & 6.5 & & & & 0.89 & \\
\hline Slovenia & $62.9(9)$ & 90.9 & 11.1 & 10.3 & 0.42 & 0.44 & 0.86 & 0.86 & 17 \\
\hline Slovakia & $69.4(3)$ & 68.6 & 7.5 & 7.3 & 0.55 & 0.54 & 0.85 & 0.81 & 8 \\
\hline
\end{tabular}

Source of data: Eurostate, Heritage Foundation (2008).

7 The "old" versus the "young" average income and the share of pensions in GDP are both strongly correlated with economic freedom index; the correlation coefficient between the "old/young" income ratio and economic freedom is -0.75 , correlation coefficient between the share of pensions in GDP and economic freedom index is -0.76 . 


\section{Graph 2}

\section{Welfare of Pensioners and Economic Freedom}

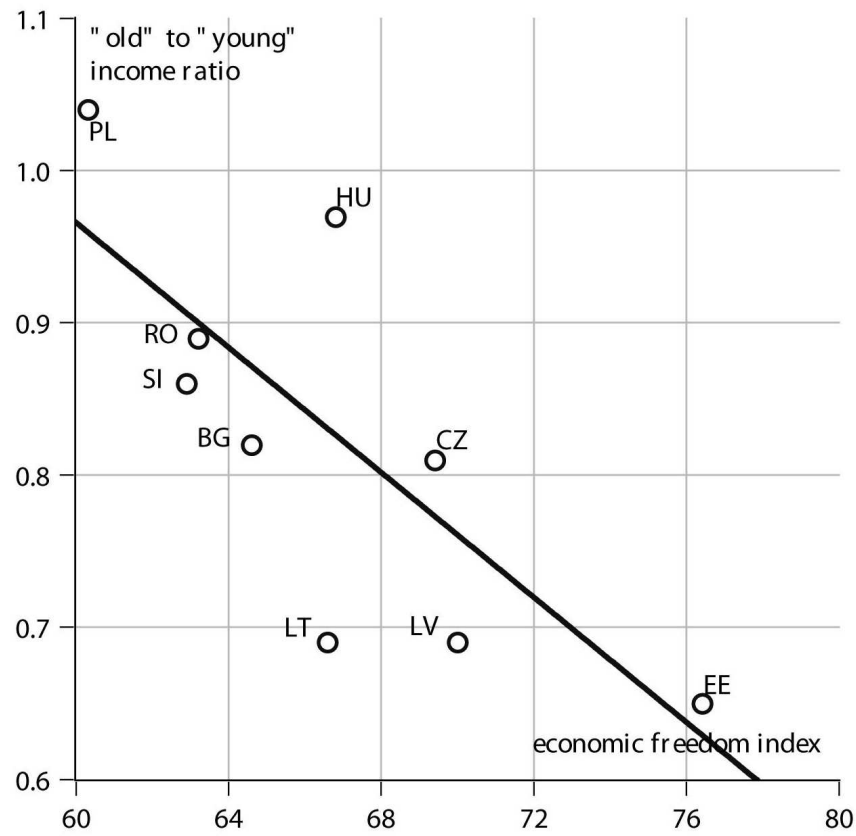

Development of the local capital market was a frequently mentioned motive for pension privatisation in the NMS, as it could be expected to boost the development of the capital market. Namely, in addition to pension funds, investment funds, hedge funds, private equity funds, and insurance companies would grow and institutional investors would gain importance. ${ }^{8}$ On the other hand, poor capital market development could be a constraint to the introduction of mandatory funded tier. If capital markets cannot provide sufficient investment projects to absorb increases in private savings, the transition from public to private pension system is unsustainable. ${ }^{9}$ Slower economic growth, lower profits and serious overvaluations of the stock market result in instable returns of private pension funds.

Some shortcomings of the reforms in the NMS were detected in the initial years. The rates of return in various funds remained below inflation rate, the operating expenses were high and not separated from the assets, the schemes were used as short-term savings by older age group rather than long-term savings for younger age groups, and the level of state contribution was not adjusted to reflect changes in wages and prices. This resulted in the dropped-off interest of citizens and the stagnating income of funds (Mácha, 2006, pp. 87-88). Further, the form of privatisation could result in a mismatch

8 About implications for financial markets see Laboul (2005).

9 Capital markets are not very well developed in the New Member States (NMSs), stock market capitalization is relatively low and the private sector relies more on bank finance ( 2.5 times more) than on stock market financing, as well the level of financial intermediation is still low but increasing. 
between market value of social assets that were to be privatised, and the value of ownership certificates given to the population (the co-called »privatisation-gap « has been a continuous issue at time of pension system reform in Slovenia). At the same time, the number of pension funds and pension management companies has mushroomed; and regarding the number of funds and companies offering pension schemes, some consolidation should occur (Stanovnik, 2006).

Privatised pension systems (funds) are pruned to procyclicality of financial and real sectors. Borio, Furfine and Lowe (2001) document the extent to which financial systems are "inherently procyclical"; that is, perceptions of value and risk move up and down with the economy as does the willingness to take risks. The financial system may be excessively procyclical and a risk of securities falling in value arises with developments on the capital market due to fluctuations of the financial results of issuers, economic expectations, cyclical movements, changes in market interest rates and exchange rates.

The private pension funds are also pruned to risk and uncertainty. The liberalisation of the global financial system and its development have sharply increased competitive pressures in the financial services industry and competitive pressures have led over time to changes in both financial structure and financial behaviour. These changes have also implied reductions in the costs of financial services. Such pressures, in turn, increase the incentives to engage in risky behaviour (Rajan, 2005). James and Brooks (2001) exposed recent experiences of capital market crises which might induce policymakers to reduce the vulnerability to capital outflows by boosting domestic savings and local capital markets.

The pension privatisation is to reduce the welfare role of the state and it could erode collective responsibility for the welfare of the vulnerable (Ginn, 2004). Gender inequality in private pension system and public private mix provisions has implications for pensioner poverty and distributional outcomes. The promotion of private pension system enables individuals to compensate for diminishing state pensions and those who cannot do so, will face the indignities of means testing the uncertainties of relying on family members for financial support. Hyde et al. (2003) argue that privatisation of pensions allows less scope for expressing the values of social cohesion, integration and inclusion.

In the private system, a membership of defined benefit occupational pensions is often unequally available to employees. Women's lower coverage than men reflects this as well as their lower employment rate. Shorter working hours and gaps in employment result in lower pension entitlements relative to men (Ginn, 2004). In state pension provision, minimum or flat-rate pension and those based on earnings years help women to obtain an independent pension. Most state pension schemes in the EU include some provisions to compensate for women's disadvantages arising from their interrupted and part-time participation in the labor market.

Private pension system has public costs and it absorbs a substantial proportion of the public subsidy in management charges, especially in case of individually arranged pension (Augulnik and Le Grand, 1998). Private pension system defends tax relieves and other subsidies to private sector pension, which is less motivated to defend declining state pensions. From the point of view of individual employee, expecting a substantial private pension, state pension may seem increasingly irrelevant, reducing 
willingness to pay contributions or join others in defending state pensions. Further, the transition costs of privatising pensions fall on the generation that is working at the time (Olsen et al., 1998). Paying for both (the existing state pension liabilities and their own funded private pensions) they bear an unfair share of the transition costs (Schokkaert and van Parijs, 2003). Private pensions are as much affected by increasing longevity as are state PAYG pensions.

Privatisation may lead to a reduction of the welfare of some generations. At the same time it may affect the workings of the labour market through the incentives for wage moderation, while reducing the size of PAYG system may increase unemployment rate. Antonis (2004) empirically proves that privatisation of pensions improves the welfare of future generations and decreases the welfare of the elderly due to reduced pension benefits of elderly.

Small volumes of corporate bond and equity insurance have created a problem for pension funds in the NMS. The growth of pension fund assets has outpaced the supply of local private securities. As a result, the pension funds may find difficult to achieve optimal asset diversification. The pension portfolios would tend to be overweighted in government assets at the expense of private securities. Rapid growth of assets under management has also affected equity markets negatively and these markets may be prone to asset price bubbles, as increased assets chase a limited number of securities. Toporowski (2000) shows that large pension funds have large economic effects, fuelling stock market inflation, share price "bubbles", a crisis in private pension funding and there is an additional risk of poor investment performance.

Modigliani (2004) tended to favour publicly funded system because of his distrust to financial markets and asset management. For him, publicly funded system based on risk-sharing via common pool assets is superior both to PAYG and to privately managed funds. Funded system according to Modigliani raises three problems: the calculation of risk in relation to projected rates of return, the costs of transitional process and volatility (if the rate of return is higher than the GDP growth).

Transferring part of the income of younger age groups to individual account in pension funds increases deficit in the PAYG system (Hausner, 2001). At the same time, voluntary savings are low due to relatively low income level of the population in transition economies. Augustinovics (2003) believes that transition to a multi-pillar pension system is not financially sustainable and it is enabled only in the suitable institutional environment. She calls for a gradual transformation of the pension systems in highly developed countries due to demographic phenomenon which have not appeared yet on a large scale in post-communist economies. Anyone not knowing the history of the public finance systems in the Eastern countries would have believed that the perfect system had been discovered, the only remaining personal problem was to forecast one's own future earning path and decide to enter or not the mixed system with the parameters of a sustainable system (more in Stiglitz, 2005).

\section{Implications and Discussion: Where Are We?}

The projections of population growth assume a rise in fertility rates in the NMS till 2050; life expectancy is also supposed to increase significantly. Thus, the dependency ratio is expected to increase which urges the reform. Two groups of proposals for 
"solving" fiscal problems related to the ageing can be distinguished: demographic and financial.

Among the demographic proposals for solving the "ageing problem" is the increase of the birth rate which would rejuvenate the population. However, beside doubts that birth rates can be affected by »demographic policies « which have in most cases created disasters and unexpected consequences (Romania, China) it is certain that the increase of birth rates would first and strongly increase "young age dependency" while affecting old age dependency much later. Beside, newly born citizens will not enter labour market at the age of fifteen but much more likely at the age of twenty five or thirty if enough new services are invented to create new jobs.

Migration also belongs to a group of demographic "solutions" of the ageing problem in EU. According to it, the problems could be solved by immigration from the countries with younger population to the countries with older population, which would alter age structure and increase payments to the pension systems. Potential positive effects are highly overstated while long-run negative economic and social impacts on emigrant and immigrant countries are completely neglected. Thus, for example, migration cuts family links and increases the need for public care for old people who could stay independent if helped by their children.

Budgetary restraint, linkage of the coverage to the level of contributions, and development of private savings and funded systems belong to financial "solutions". It is, however, not at all obvious that they could provide solutions; they would create redistribution without increasing the funding. Strengthening linkage between contributions and benefits would establish a new distribution of payments and benefits, and abandonment of the principle of solidarity. Fully funded system is also affected by a shrinking active population, and the sole shift from the PAYG system to fully funded system would bring unbearable burden to the currently active generation. There are three possible strategies to finance the transition costs: first, by redirecting contributions from the Social Security to private pension funds and to accept an increase in general government deficit. The drop in general government savings exactly compensates for the rise in households savings. If pension funds are invested in the newly issued public bonds, the reform transforms the implicit debt of the PAYG system into an explicit more expansive public debt. When transition is over, workers will pay less social contributions and more taxes, for the government to pay interest rates and to cover increased debt. The government could also use the second strategy (»internalfinancing «) i.e. to cut in current public pensions (Dupont, 2004). If contributions to private funds help to finance a rise in investment activity, the economic outlook improves in the short run. But if investment activity did not rise, the negative economic and social outlook follows. And the third strategy pretends the possibility of increasing social contributions.

The second pillar based on the expected growth of financial wealth managed by public or private pension funds implies sharing the ups and downs of the world financial market; the capital would most likely disappear in "black holes" of the financial systems.

The privatisation of the pension system, which is being considered as promising choice does not assure secure incomes for elderly. On the contrary, the increased choice and higher returns which are considered to be the advantages of the private 
pension funds cannot be achieved without enormous risks, which majority of people cannot afford and are not even aware of. The market does not guarantee returns nor that the value of financial investment would remain unchanged; transaction costs of private pension funds (the earnings of their managers) are higher than transaction costs of public pension funds. The care for "old" can also not be simply shifted from the public to the private sector. Indeed, the consequences of the privatisation could be catastrophic both for the pensioners and for the public finance. If private pension fund collapses; the government cannot avoid responsibility for the pensioners affected by a collapse of the fund which would leave many old people in poverty.

Problems of pension financing at present are not predominantly the result of demographic changes but of unemployment, low wages and a shift in the distribution of incomes to the disadvantage of the wage side, which is the financial basis of PAYG systems. The reason for the slowdown in economic growth during the last two decades is not the absence of savings; rather it is due to weakness of effective demand.

If the shift towards capital market based systems does not create additional growth its only effect will be a more unequal distribution of pensions between those who could afford additional individual savings during their active lifetime and those who could not. Pensions linked to capital markets are exposed to a much higher degree of economic and social insecurity than pensions in a PAYG system because the ups and downs of financial markets are much more accentuated than the amplitudes of regular business cycles.

While the perspective to privatise pensions may include the promise of large profits to the financial industry it offers little benefits to workers, citizens and future pensioners. The administrative and management costs of private decentralized systems are much higher than of centralized public systems (Mitchell et al., 1996). Public PAYG systems are much less costly to regulate and more comprehensive in their coverage (concerning for instance periods of unemployment and sickness) than privately funded systems which are much more selective.

Current stampede towards privatisation and capital funding is not the solution; instead it would exacerbate problems of social welfare. Pension funds, investment funds, and insurance companies have a major interest in the transformation of public PAYG systems into capital market based (private) systems. Financial institutions namely receive substantial amounts of workers contributions to private social security systems, which they can invest on financial markets. However, this clear interest of asset managers and considerable power of financial institutions should not be confounded with the public interest or social welfare in general.

Continuous increases in productivity create the basis for rising real incomes both for the working population and for pensioners even under conditions of higher dependency rate. The most important way to ensure financial stability and sustainability of these systems is to strengthen the productive basis of the economy through a policy for full employment at high wages, which includes also policies to enhance and stabilize supply of labour. On the basis of rising labour productivity these contributions can be increased so as to insure a decent living standard for the pensioners.

A multi-pillar pension system with traditional PAYG system as the first and crucial pillar, a funded second pillar based on the employment relationship, and the third pillar based on individual initiative (Daykin, 2004) appears to be a reasonable solution. 


\section{References}

Antonis, A. (2004), Macroeconomic Effects of Social Security Privatization in a Small Unionized Economy. Athens: Athens University of Economics and Business.

Augulnik, P.; Le Grand, J. (1998), "Tax Relief and Partnership Pensions." Fiscal Studies 19 (4): pp. 403-428.

Augustinovics, M. (2003), "Pension Systems and Reforms in the Transition Economies." ONU CEE Economic Survey of Europe 1999 (3): Chapter 4.

BACA. (2007), Overview of Taxes, Incidental Wage Cost, Pension Systems in the NMS-5, April. [http:// economicresearch-e.ba-ca.com].

Bole, V. (1998), "Financing the Transition of the Public Pension System in Slovenia." Ministry for Finance, Republic of Slovenia (mimeo).

Borio, C., Furfine, C., Lowe, P. (2001), "Procyclicality of the Financial System and Financial Stability: Issues and Policy Options", in Marrying the Macro and Micro-Prudential Dimension of Financial Stability (Bank for International Settlements, March, No. 1), pp. 24-31. Available at http://www. bis.org.

Clon-Dominczak, A. (2002), "The Polish Pension Reform of 1999." In Pension Reform in Central and Eastern Europe, E. Fultz (ed.), Vol. 1. Geneva: ILO.

Databases: Eurostat, OECD and EIPF (2007).

Daykin, C. (2004), "Approaches to Pension Reform." Available at http://www.actuaries.org/PBSS/ Documents/Approaches_Pension_Reform.pdf.

Disney, R., Johnson, P. (2001), Pension Systems and Retirement Incomes across OECD Countries. Northampton: Edward Elgar.

Disney, R. (2003), "Public Pension Reform in Europe: Policies, Prospects and Evaluation." The World Economy 26 (10): pp. 1425-1445.

DREE (2003), "Pension Reform in CEEC." Revue Élargissement, June (46): pp. 115-129.

Dupont, G. (2004), "Pensions Reforms in Acceding Countries." OFCE Analysis and Forecasting Department, Special Issue, April, pp. 56-81.

European Commission (2003). The Social Situation in the EU. Available at http://ec.europa.eu/ employment_social/publications/2003/keag03001_en.html.

Ginn, J. (2004), "European Pension Privatization: Taking Account of Gender." Social Policy and Society 3 (2): pp. 123-134.

Grimmeisen, S. (2003), "Path Departure and Path Dependence: the Case of Post-Communist Pension Reform in Hungary, Poland and the Czech Republic." In Contribution to the ESPAnet 2003 Conference, November. Copenhagen: ESPA.

Gruber, J., Wise, D. (2003), "Social Security Programs and Retirement Around the World." NBER Working Paper, No. 9407.

GVG. (2002), "Study on the Social Protection Systems in the 13 Applicant Countries." Study financed by the European Commission. Available at http:europa.eu.int/enployment_social/soc-prot/social/ index_en.htm.

Hausner, J. (2001), "Security through Diversity: Conditions for Successful Reform of the Pension System in Poland." In Feldstein, M., Siebert, H. eds., Social Security Pension Reform in Europe, pp. 349-364. Chicago: Chicago University Press.

Hyde, M., Dixon, J., Drover, G. (2003), "Welfare Retrenchment or Collective Responsibility? The Privatization of Public Pensions in Western Europe." Social Policy and Society 2 (3): pp. 189-198.

James, E., Brooks, S. (2001), "The Political Economy of Structural Pension Reform." In Holzman, R., Stiglitz, J. E., eds., New ldeas about Old-Age Security: toward Suitable Pension System in the 21st Century. Washington: The World Bank.

Laboul, A. (2005), "Ageing and Pension System Reform: Implications for Financial Markets and Economic Policies." IMF. Available at http://www.imf.org/external/np/g10/2005/pdf/092005.pdf. 
Mácha, M. (2006), "The Political Economy of Pension System Reform in the Czech Republic." In Salomäki, A. ed., Public Pension Expenditure in the EPC and the European Commission Projections: an Analysis of the Projection Results. Brussels: Directorate General for Economic and Financial Affairs.

Mencinger, J. (2007), "So upokojenci nevarnejši od globalnega segrevanja (Are Pensioners More Dangerous than the Global Warming)." Gospodarska gibanja, pp. 7-8: 6-13.

Mencinger, J. (2008), "Do Pensioners Endanger Fiscal Stability in the EU Countries?" Pensions: An International Journal, vol. 13, no 4, pp. 227-235.

Mitchell, O., Dykes, E. L. (2000), "New Trends in Pension Benefit Retirement Provisions." In A Report to the Pension and Welfare Benefits Administration, Pension Research Council. University of Pennsylvania: Wharton School. Available at http://knowledge.wharton.upenn.edu/papers/1207. pdf.

Mitchell, O. et al. (1996), "Administrative Costs in Public and Private Retirement Systems." NBER Working Paper, No. 5734, August. Cambridge: NBER MA Press.

Modigliani, F., Muralidhar, A. (2004), Rethinking Pension Reform. Cambridge: Cambridge University Press.

Müller, K. (2002), "Pension Reform Paths in Central-Eastern Europe and the Former Soviet Union." Social Policy and Administration 36 (2): pp. 123-143.

Natali, D. (2004), "The Hybridization of Pension Systems within the Enlarged EU, Recent Reforms and Old and New Members." In Research Assistant at the Observatories Social Européen, the Revue belge de sécurité sociale. http://www.ose.be/files/mocpension/RBSS2004DNenWorkdoc.pdf.

Nelson, M. J. (2001), "The Politics of Pension and Health Care Reforms in Hungary and Poland." In Kornai, J., Haggard, S., Kaufman, R., eds., Reforming the State, Fiscal and Welfare Reform in Post-Socialist Countries. Cambridge: Cambridge University Press.

Novak, A. (2004), Pension System Reform in Slovenia. Europe-Asia Studies, Volume 56 (2): pp. 279-292.

Olsen, A. K., VanDerhei, J., Salisbury, D. L., Holmer, M. R. (1998), "How Do Individual Society Security Accounts Stack Up?" An evaluation using the EBRI-SSASIM2 policy simulation model, EBRI issue brief No. 195, March. Washington: D.C. Employee Benefits Research Institute.

Orenstein, A. M. (2003), "Mapping the Diffusion of Pension Innovation." In Holzmann, R., Orenstein M., Rutkowski, M., eds., Pension Reform in Europe: Process and Progress, Washington: World Bank, DC.

Orszag, P., Stiglitz, J. (2001), "Rethinking Pension Reform: Ten Myths about Social Security Systems." In Holzman, R., Stiglitz, J., eds., New Ideas about Old Age Security: towards Sustainable Pension Systems in the 21st Century, pp. 17-62. Washington: The World Bank, D. C.

Rajan, G. R. (2005), "Has Financial Development Made the World Riskier?" Paper presented at the Jackson Hole Conference, August. Available at http://neweconomist.blogs.com/ new_economist/2005/papers_from_the-html.

Salomäki, A. (2006), "Public Pension Expenditure in the EPC and the European Commission Projections: an Analysis of the Projection Results." In European Economy, Economic papers by European Commission, No. 268. Brussels: Directorate General for Economic and Financial Affairs.

Schokkaert, E., van Parijs, P. (2003), "Social, Justice and the Reform of Europe's Pension Systems." Journal of European Social Policy 13 (3): pp. 245-263.

Stanovnik, T. (2006), "The Political Economy of Pension System Reform in Slovenia." In Salomäki, A., ed., Public Pension Expenditure in the EPC and the European Commission Projections: an Analysis of the Projection Results. Brussels: Directorate General for Economic and Financial Affairs.

Stiglitz, E. J. (2005), "Securing Social Security for the Future." The Economists`Voice 1 (2): Article 5. Toporowski, J. (2000). The End of Finance. London: Routledge.

World Bank (1994). Averting the Old Age Crisis. Washington: World Bank. 